\title{
PENINGKATAN PRESTASI BELAJAR MATEMATIKA MELALUI PEMBELAJARAN KONTEKSTUAL DI SEKOLAH DASAR
}

\author{
Annisa Rizqi Maryani*, Arifin Muslim, Pamujo \\ PGSD, Universitas Muhammadiyah Purwokerto, Indonesia
}

\begin{tabular}{|c|c|}
\hline Article History & \multirow{6}{*}{$\begin{array}{l}\text { Abstrak } \\
\text { Latar belakang penelitian ini adalah rendahnya prestasi belajar siswa } \\
\text { sekolah dasar pada mata pelajaran matematika. Penelitian ini bertujuan } \\
\text { untuk meningkatkan prestasi belajar matematika melalui pembelajaran } \\
\text { kontekstual. Penelitian ini merupakan penelitian tindakan kelas yang } \\
\text { terdiri dari } 2 \text { siklus. Setiap siklusnya terdiri dari } 2 \text { pertemuan. Penelitian } \\
\text { ini terdiri dari empat tahapan, yaitu perencanaan, tindakan, observasi, } \\
\text { dan refleksi. Subjek dari penelitian ini adalah siswa kelas IV SD Negeri } \\
\text { Kaliwadas o1 yang terdiri dari } 14 \text { siswa laki-laki dan } 11 \text { siswa perempuan. } \\
\text { Alat pengumpulan data yaitu lembar soal evaluasi, lembar observasi } \\
\text { aktivitas guru, lembar observasi aktivitas siswa. Hasil penelitian } \\
\text { menunjukkan adanya peningkatan pada setiap siklusnya. Peningkatan } \\
\text { prestasi belajar terlihat pada setiap siklusnya. Pada siklus I memperoleh } \\
\text { rata-rata } 110.87 \text { dengan ketuntasan belajar } 55 \% \text { dan siklus II memperoleh } \\
\text { rata-rata } 164.18 \text { dengan ketuntasan sebesar } 82 \% \text {. Peningkatan dari siklus } \\
\text { I ke siklus II adalah } 27 \% \text {. Hasil penelitian ini menunjukkan bahwa } \\
\text { melakukan pembelajaran matematika dengan menggunakan } \\
\text { pembelajaran kontekstual dapat meningkatkan sikap tanggung jawab } \\
\text { dan prestasi belajar matematika. }\end{array}$} \\
\hline Submitted: July 29, 2020 & \\
\hline Accepted : Feb 19, 2020 & \\
\hline Published : Feb 20, 2020 & \\
\hline Kata Kunci & \\
\hline & \\
\hline
\end{tabular}

\section{PENDAHULUAN}

Proses pembelajaran yang berhasil di sekolah dipengaruhi banyak faktor. Salah satu faktor tersebut adalah penggunaan atau pemilihan model, metode, pendekatan, media yang tepat, sesuai dengan isi materi dan tujuan pembelajaran. Pembelajaran merupakan suatu kegiatan belajar mengajar yang dilakukan oleh seorang guru dengan siswanya. Menurut Susanto pembelajaran merupakan komunikasi dua arah, mengajar dilakukan oleh pihak guru sebagai pendidik, sedangkan belajar dilakukan oleh peserta didik. Sehingga pembelajaran juga dapat dimaknai sebuah proses mentransfer pengetahuan dari seseorang ke orang lain yang belum mengetahui suatu hal (Susanto, 2015, p. 185).

Pembelajaran matematika merupakan pelajaran yang sangat penting di sekolah dasar. Hal ini karena matematika adalah mata pelajaran yang akan selalu digunakan dalam kehidupan dan ilmu-ilmu lain. Siswa di sekolah dasar masih dalam tahap operational konkret yaitu dimana siswa belajar dengan hal-hal ataupun benda-benda nyata yang ada di sekitarnya. Materi pembelajaran dalam matematika juga harus berhubungan dengan kehidupan yang dialami siswa.

Prestasi belajar siswa kelas IV masih rendah dalam pelajaran matematika, pada materi pengukuran sudut. Hal ini disebabkan karena proses pembelajaran yang dilakukan masih kurang maksimal, siswa masih belum bisa memahami materi dengan 
baik dan juga penalaran terhadap soal yang masih kurang, serta sikap tanggung jawab sebagai siswa dalam mengerjakkan tugas masih rendah. Selain itu juga tingkat keterlibatan siswa dalam proses pembelajaran masih kurang akibat kurang tepatnya penggunaan model/ metode pembelajaran. Permasalahan ini membuat prestasi belajar siswa rendah pada pelajaran matematika.

Bedaraskan permasalahan tersebut, peneliti mencoba menyelesaikan permasalahan tersebut dengan menggunakan Contextual Teaching and Learning atau pembelajaran kontekstual. Berdasarkan penelitian yang dilakukan oleh Andari tentang efektivitas pembelajaran matematika menggunakan pendekatan kontekstual terhadap prestasi belajar matematika ditinjau dari kemampuan awal siswa kelas bahwa pendekatan kontekstual dapat meningkatkan prestasi belajar matematika dibandingkan dengan yang menggunakan pembelajaran konvensional (Andari, 2012).

Pembelajaran kontekstual merupakan pembelajaran yang mengaitkan pelajaran dengan kehidupan nyata siswa, sehinga pembelajaran tersebut akan lebih bermakna bagi siswa. Menurut Johnson, pengajaran dan pembelajaran kontekstual melibatkan para siswa dalam aktivitas penting yang membantu mereka mengaitkan pelajaran akademis dengan konteks kehidupan nyata yang mereka hadapi (Johnson, 2014, p. 35). Berdasarkan pendapat tersebut diharapkan pembelajaran matematika menggunakan pembelajaran kontekstual dapat meningkatan prestasi belajar matematika di kelas IV.

\section{METODE DAN FOKUS PENELITIAN}

Jenis penelitian yang dilakukan dalam penelitian ini adalah Penelitian Tindakan Kelas (Classroom Action Research). Penelitian tindakan kelas ini dilaksanakan sebanyak dua siklus, yaitu siklus 1 dan siklus 2. Penelitian yang dilakukan untuk meningkatkan sikap tanggung jawab dan prestasi belajar matematika siswa dengan materi pengukuran sudut menggunakan pembelajaran kontekstual. Model yang digunakan penelitian ini adalah model Penelitian Tindakan Kelas menurut Kemmis dan McTaggart yang menggunakan sistem spiral yang terdiri dari beberapa siklus. Subjek dari penelitian ini adalah siswa kelas IV yang berjumlah 25 siswa terdiri dari 14 siswa laki-laki dan 11 siswa perempuan.

Teknik pengumpulan data dalam penelitian ini menggunakan teknik tes dan non tes. Tes untuk lembar soal evaluasi, dan non tes untuk lembar observasi aktivitas guru dan aktivitas siswa.

\section{HASIL DAN PEMBAHASAN}

Pembelajaran dengan menggunakan pembelajaran kontekstual dapat meningkatkan prestasi belajar siswa, hal ini karena pembelajaran kontekstual merupakan pembelajaran yang mengaitkan antara materi dengan kehidupan nyata siswa sehingga pembelajaran akan terasa lebih bermakna bagi siswa. 
Tabel 1. Hasil Evaluasi

\begin{tabular}{|c|c|c|c|c|c|}
\hline \multirow[t]{2}{*}{ No. } & \multirow[t]{2}{*}{ Siklus/Pertemuan } & \multicolumn{2}{|c|}{ Jumlah siswa } & \multirow{2}{*}{$\begin{array}{c}\text { Rata-rata } \\
\text { kelas }\end{array}$} & \multirow{2}{*}{$\begin{array}{c}\text { Ketuntasan } \\
(\%)\end{array}$} \\
\hline & & Tuntas & Belum & & \\
\hline 1. & $\mathrm{I} / \mathrm{1}$ & 12 & 12 & 72.50 & 50 \\
\hline 2. & $\mathrm{I} / 2$ & 14 & 9 & 67.83 & 61 \\
\hline 3. & II/ 1 & 24 & 1 & 87.60 & 96 \\
\hline 4. & II / 2 & 15 & 7 & $75 \cdot 91$ & 68 \\
\hline \multicolumn{4}{|c|}{ Rata - Rata Siklus I } & 110.87 & 55 \\
\hline \multicolumn{4}{|c|}{ Rata - Rata Siklus II } & 164.18 & 82 \\
\hline
\end{tabular}

Berdasarkan tabel di atas hasil dari prestasi belajar siswa dapat disajikan pada gambar berikut:

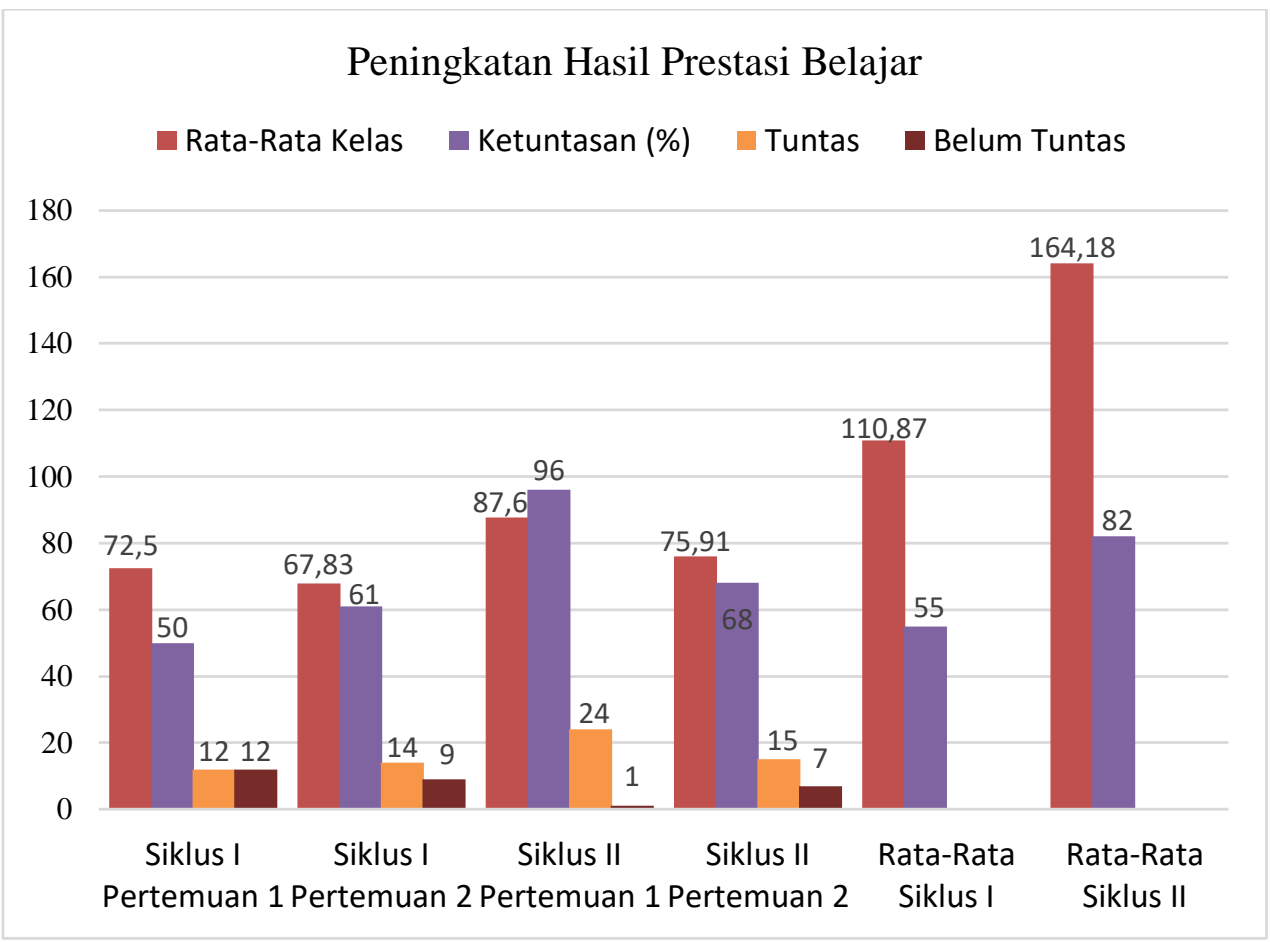

Gambar 1. Histogram Hasil Prestasi Belajar

Berdasarkan hasil Penelitian Tindakan Kelas yang telah dilakukan, terdapat peningkatan dari siklus I ke siklus II. Hal ini membuktikan bahwa pembelajaran kontekstual dapat meningkatkan hasil prestasi belajar. Pembelajaran kontekstual merupakan pembelajaran yang membuat siswa menjadi lebih aktif, mandiri, bertanggung jawab dalam pembelajaran. Terbukti pada pembelajaran siswa terlihat Prestasi belajar menurut Djamarah adalah hasil dari suatu kegiatan yang telah dikerjakan, diciptakan, baik secara individual maupun kelompok (Djamarah, 2012, p. 19). Berdasarkan pengertian tersebut, dapat disimpulkan bahwa prestasi merupakan sebuah pencapaian seseorang dalam meraih sesuatu yang diinginkannya melalui usaha.

Penelitian yang telah dilakukan oleh peneliti menjelaskan bahwa pembelajaran kontekstual menjelaskan bahwa penelitian ini dapat meningkatkan sikap tanggung jawab dan prestasi belajar siswa. Peningkatan ini dilihat dari adanya temuan baru yang 
peneliti dapatkan saat penerapan pembelajaran kontekstual. Temuan baru tersebut adalah pembelajaran kontekstual dapat meningkatkan sikap kerja sama siswa. Jadi, selain dapat meningkatkan sikap tanggungjawab, pembelajaran kontekstual juga dapat meningkatkan kerjasama dan prestasi belajar.

Penelitian yang dikemukakan oleh Mahendrawan, Wayan dan Made (2014) menyatakan bahwa pembelajaran kontekstual juga melatih kerjasama siswa dalam kelompok belajar. Selain kerjasama terdapat juga interaksi sosial, bertukar pengetahuan dan menghargai pendapat atau gagasan anggota kelompok. Pada pembelajaran kontekstual yang telah dilakukan leh peneliti juga menunjukkan adanya kerjasama, interaksi, dan saling bertukar pengetahuan, sehingga hal ini membuat siswa lebih belajar dan lebih mengetahui materi dengan baik. Maka dari itu, prestasi belajar siswa meningkat.

\section{PENUTUP}

Penerapan pembelajaran kontekstual pada mata pelajaran matematika kelas IV dapat meningkatkan hasil prestasi belajar siswa. Hal ini dibuktikan dengan hasil evauasi yang mengalami peningkatan ketuntasan dari siklus I rata-rata 110.87 dengan ketuntasan belajar 55\% dan siklus II rata-rata 164.18 dengan ketuntasan belajar klasikal sebesar 82\%. Pembelajaran kontekstual efektif dalam meningkatkan prestasi belajar, karena pembelajaran kontektual selalu melibatkan siswa dalam pembelajaran sehingga pembelajaran dapat bermakna bagi siswa. Pembelajaran kontekstual juga membuat siswa lebih mudah dalam memahami materi yang diajarkan oleh guru. Pembelajaran menggunakan pembelajaran kontekstual dapat menjadi salah satu alternatif guru untuk meningkatkan prestasi belajar matematika. Selain itu, hendaknya guru dan siswa mempersiapkan terlebih dahulu jika ingin melakukan pembelajaran kontekstual agar pembelajaran dapat berjalan sempurna.

\section{REFERENSI}

Andari, T. (2012). Efektivitas Pembelajaran Matematika Menggunakan Pendekatan Kontekstual Terhadap Prestasi Belajar Matematika Ditinjau dari Kemampuan Awal Siswa Kelas V SD Se-Kecamatan Bangunrejo Kabupaten Lampung Tengah. Jurnal Ilmiah Pendidikan Matematika, 1(1). Retrieved from http://ejournal.unipma.ac.id/index.php/jipm/article/view/465.

Djamarah, S.B. (2012). Prestasi Belajar dan Kompetensi Guru. Surabaya: Usaha Nasional.

Johnson, E.B. (2014). CTL (Contextual Teaching E Learning) Menjadikan Kegiatan Belajar-Mengajar Mengasyikan dan Bermakna. Bandung: Kaifa Learning

Mahendrawan I P., I Wayan S., \& I Made S. (2014). Penerapan Pendekatan Kontekstual Untuk Meningkatkan Hasil Belajar Matematika Siswa Kelas IV Sekolah Dasar Kelas V No. 1 Tukadsumaga. Jurnal Mimbar PGSD Universitas Pendidikan Ganesha, 2(1).

Susanto, A. (2015). Teori Belajar dan Pembelajaran di Sekolah Dasar. Jakarta: Prenada Media Group. 